\title{
Effects of Protein and/or Energy Restriction for Six Weeks, Followed with Nutritional Recovery on the Antioxidant Capacity and Development of Liver, Spleen and Muscle of Weaned Kids
}

\author{
Tan Yang ${ }^{1}$, Zhihong Sun ${ }^{1,2}$, Zhixiong $\mathrm{He}^{2}$, Shimin $\mathrm{Liu}^{3}$, Qingli Zhang ${ }^{4}$, Xiaomin $\mathrm{Li}^{1}$, Zhiliang $\operatorname{Tan}^{2}$, \\ Xuefeng $\mathrm{Han}^{2}$, Shaoxun Tang ${ }^{2}$, Chuanshe Zhou ${ }^{2} \&$ Min Wang ${ }^{2}$ \\ ${ }^{1}$ College of Animal Sciences and Technology, Southwest University, Chongqing, China \\ ${ }^{2}$ Key Laboratory of Agro-ecological Processes in Subtropical Region, Institute of Subtropical Agriculture, the \\ Chinese Academy of Sciences, Changsha, China \\ ${ }^{3}$ Faculty of Natural and Agricultural Sciences, The University of Western Australia, Crawley, Australia \\ ${ }^{4}$ College of Animal Sciences and Technology, Northwest A \& F University, Yangling, China \\ Correspondence: Zhihong Sun, College of Animal Sciences and Technology, Southwest University, Chongqing \\ 400715, China. Tel: 86-23-6825-0170. E-mail: sunzh2002cn@yahoo.com.cn
}

Received: June 25, 2012 Accepted: July 23, 2012 Online Published: October 12, 2012

doi:10.5539/jas.v4n11p235 URL: http://dx.doi.org/10.5539/jas.v4n11p235

Thanks go to the Key Projects in the National Science \& Technology Pillar Program (2011BAD36B01 \& 2012BAD14B18); National Program on Key Basic Research Project of China (2013CB127300); Doctoral Fund of Southwest University (The Program of Talent Introduction, No.SWU110054); the Fundamental Research Funds for the Central Universities (XDJK2011B011); the National Natural Science Foundation of China (No.30600436) and the Key Technologies R \& D Program of Changsha City (K1101189-21).

\begin{abstract}
The effects of protein and/or energy restrictions on the antioxidant capacity and development of liver, spleen and muscle were investigated in kids. Sixty Liuyang Black kids, weaned at 28-day old, were allocated to four treatments: control, either energy or protein restriction, and combined energy and protein restriction. The experimental period consisted of six weeks of nutritional restriction followed with nine weeks of nutritional recovery. On day 42, energy restriction decreased the activity of glutathione peroxidase (GSH-Px) in spleen, the superoxide dismutase (SOD) mRNA level in muscle and spleen, and the ratio of RNA to DNA in liver $(\mathrm{P}<0.05)$; protein restriction decreased the activity of glutathione reductase (GR) in muscle and liver, the ratio of RNA to DNA in liver, and the $\mathrm{N}$ concentration and the ratio of $\mathrm{N}$ to DNA in spleen and muscle $(\mathrm{P}<0.05)$; combined restriction of energy and protein decreased the activities of catalase and GR and the ratio of RNA to DNA in muscle, and the activities of SOD, GSH-Px and GR in spleen $(\mathrm{P}<0.05)$. On day 105, there was no difference in the antioxidant parameters among four groups $(\mathrm{P}>0.05)$; however, the weights of liver and spleen in groups of pre-protein restriction and pre-combined restriction of energy and protein were still less than those of kids in control. The results indicate that six weeks of nutritional restriction can reduce the antioxidant capacity of muscle, spleen and liver, retard the development of liver and spleen, and the retarded development partly continues even after nine weeks of nutritional recovery.
\end{abstract}

Keywords: weaned goats, nutrient restriction, antioxidant capacity, development

\section{Introduction}

\subsection{Introduce the Problem}

Intensive ruminant meat production systems are becoming more common worldwide. In this kind of production system, the young meat ruminant was usually early weaned. The meat ruminant, especially pregnancy and newborn (0-3 months after birth) are often in face of a lack of protein and energy, especially in the dry season and winter. 


\subsection{Explore Importance of the Problem}

Malnutrition during critical periods of animal development may have long-term programming effects on later growth and health, as being supported by evidence from epidemiological studies, clinical intervention trials and numerous animal models (Aguilera et al., 2003; Fukuda et al., 2002; Petry et al., 2001).

\subsection{Describe Relevant Scholarship}

Previous studies have proven that nutritional restriction such as energy and protein delay the development of tissues (Sainz \& Bentley, 1997; McLeod \& Baldwin, 2000; Shen et al., 2004) and compensatory growth, defined as a phase of accelerated growth when favorable conditions are restored after a period of growth depression (Fabian et al., 2007; Heyer \& Lebret, 2007). Previous studies also found that the deficiency of dietary protein and energy can lead to change the antioxidation capacity of tissues, such as reducing the concentrations of glutathione (GSH) and activity of superoxide dismutase (SOD) (Ogasawara et al., 1989), and further arouse an oxidative stress (Marks et al., 1996; Li et al., 2002), which retarded the development of tissues or organs though changing digestion and absorption ( $\mathrm{Li}$ et al., 2010), nutrient metabolism (Robertson et al., 2003) and immune function (Tohyama et al., 2004).

\subsection{State Hypotheses and Their Correspondence to Research Design}

Therefore, we suppose that nutritional deficiency may more easily result in the reduction of antioxidant capacity of the early weaned meat ruminants, and the reduced antioxidant capacity may be one of the main reasons for the retardation of tissue development. In order to prove our hypothesis, this study was carried out to investigate the effects of restriction of protein and/or energy for six weeks, followed with nutritional recovery for nine weeks on antioxidant of muscle, liver and spleen and the development of liver and spleen of 28-d weaned kids.

\section{Method}

\subsection{Animal Use and Care}

The experiment was conducted according to the Animal Care and Use Guidelines of Institute of Subtropical Agriculture, the Chinese Academy of Sciences, Changsha.

Sixty healthy kids were obtained from 50 female Liuyang Black goat (local breed) nannies, with all offsprings being born within two days of each other. After birth, the kids were maintained with their mothers for nursing naturally, and weaned after four weeks. The weaned kids were kept individually in stainless steel metabolic cages, which were located in an animal house with ambient temperature controlled constantly at $21^{\circ} \mathrm{C}$.

\subsection{Experimental Diets}

The weaned kids were randomly stratified by body weight to four dietary treatments with eight male and seven female in per group and the twins were distributed into different groups. The four groups of the animals were then allocated respectively to four dietary treatments: control (dried ryegrass hay + starter ration), energy restriction (ER, dried ryegrass hay $+40 \%$ reduction of energy in starter feed), protein restriction (PR, dried ryegrass hay $+40 \%$ reduction of protein in starter feed), and combined protein and energy restriction (EPR, dried ryegrass hay $+40 \%$ reduction of both protein and energy in starter feed). The control ration (the forage plus the start diet) was offered to meet 1.4 times of the maintenance requirement for metabolic energy according to Lu et al. (1996). The ingredients and composition of the starter ration are given in Table 1. The crude protein (CP) content and calculated metabolizable energy (ME) of dried ryegrass hay were $14 \%$ and $8.04 \mathrm{MJ} / \mathrm{kg}$ respectively.

The whole experiment lasted for sixteen weeks. After weaning, one week of the acclimatization period was allowed for the kids to adapt to the control ration and the environment. Then the nutritional restriction started (day 1) and lasted for six weeks (day 42), followed with a period of nine weeks for the nutritional recovery, so there was a total of 105 days for formal experiment. During the nutritional recovery period, the ration for all experimental animals was changed. Ryegrass was replaced with maize stover (CP: $5.50 \%$; ME: $5.80 \mathrm{MJ} / \mathrm{kg}$ ) and the starter feed was replaced with the concentrate, and to meet 1.3 times of the maintenance requirement for metabolic energy according to $\mathrm{Lu}$ et al. (1996). The ingredients and composition of the concentrate are also shown in Table 1. During both the periods of nutritional restriction and nutritional recovery, the same amounts of the rations (ryegrass plus the starter feed, and maize stover plus the concentrate) were offered to the kids among the four groups, and the ratios of starter feed to ryegrass hay and concentrate to maize stover were 40:60 and 50:50 in dry weight respectively. The ration was divided into two equal portions and fed to the kids at 07:00 $\mathrm{h}$ and 19:00 $\mathrm{h}$ respectively. All kids had ad libitum access to fresh water.

\subsection{Measurements and Sampling}

For the entire experimental period, the amounts of feed offered and orts collected prior to the feeding were 
recorded daily, and the daily feed intake was calculated. The kids were weighed on days 1,42 and 105 prior to the morning feeding and the weights were used to calculate the averaged daily body weight gains (BWG) over the periods of nutritional restriction and nutritional recovery respectively.

On d 42 (ie, the end of nutrient restriction) and d 105 (the end of nutrient recovery) of the experimental day, three kids with similar body weights from each group were anaesthetized with an intravenous injection of sodium pentobarbital (50 mg/kg BW) and bled for exsanguinations, respectively. Then the abdominal cavity of the kid was opened, and the viscera were removed. The liver and spleen were separated and weighted. Liver sample (about $4 \mathrm{~g}$ ) at top right leaf, whole spleen and the longissimus dorsi between 8 th and 12 th ribs from right side were collected, immediately frozen in liquid $\mathrm{N}$ and stored at $-80^{\circ} \mathrm{C}$ for later analysis.

Table 1. Dietary ingredients and composition of starter feed in nutritional restriction period and concentrate in nutritional recovery period (dry matter basis)

\begin{tabular}{|c|c|c|c|c|c|}
\hline & \multicolumn{4}{|c|}{ Starter feed } & \multirow{2}{*}{ Concentrate } \\
\hline & Control & ER & PR & EPR & \\
\hline \multicolumn{6}{|l|}{ Ingredients (\%) } \\
\hline Corn & 25.0 & 22.8 & 43.7 & 39.1 & 56.0 \\
\hline Soybean meal & 15.0 & 10.0 & 8.00 & 5.00 & 15.1 \\
\hline Whey & 8.00 & 5.00 & 6.00 & 5.00 & - \\
\hline Milk replacer ${ }^{2}$ & 3.70 & 5.00 & 8.00 & - & - \\
\hline Wheat & - & 10.0 & - & 15.0 & - \\
\hline Wheat middling & 2.00 & 1.70 & - & - & - \\
\hline Wheat bran & - & - & - & - & 12.0 \\
\hline Fishmeal & 6.00 & 3.00 & 4.90 & - & 2.00 \\
\hline Fat powder & 20.0 & - & 20.2 & - & \\
\hline Yeast powder & - & - & - & - & 10.5 \\
\hline Lactose & - & - & 5.00 & - & - \\
\hline Corn gluten meal & 16.4 & - & - & - & - \\
\hline Rapeseed cake & - & 8.00 & - & 3.70 & - \\
\hline Blood meal & - & 5.40 & - & - & - \\
\hline Alfalfa meal & - & 26.0 & - & 28.0 & - \\
\hline Limestone & 0.70 & 0.10 & 0.70 & 0.40 & 1.50 \\
\hline Dicalcium phosphate & 0.30 & 0.30 & 0.70 & 0.90 & 0.50 \\
\hline Sodium bicarbonate & - & - & - & - & 0.40 \\
\hline Salt & 0.80 & 0.70 & 0.90 & 0.80 & 1.00 \\
\hline Premix $^{3}$ & 2.00 & 2.00 & 2.00 & 2.00 & 1.00 \\
\hline \multicolumn{6}{|l|}{ Composition } \\
\hline CР (\%) & 23.5 & 23.8 & 14.3 & 14.6 & 22.2 \\
\hline ME (MJ/kg) & 17.9 & 11.2 & 17.9 & 11.2 & 13.4 \\
\hline Calcium (\%) & 0.90 & 0.90 & 0.90 & 0.90 & 0.90 \\
\hline Phosphorus (\%) & 0.60 & 0.60 & 0.60 & 0.60 & 0.60 \\
\hline
\end{tabular}

$\mathrm{ER}=$ energy restriction; $\mathrm{PR}=$ protein restriction; $\mathrm{EPR}=$ combined energy and protein restriction;

Contained per kg of milk replacer: $335 \mathrm{~g}$ milk, $350 \mathrm{~g}$ whey powder, $125 \mathrm{~g}$ lactose and $200 \mathrm{~g}$ fat powder;

Contained the following per kg of premix: $119 \mathrm{~g} \mathrm{MgSO}_{4} \cdot \mathrm{H}_{2} \mathrm{O}, 2.5 \mathrm{~g} \mathrm{FeSO}_{4} \cdot 7 \mathrm{H}_{2} \mathrm{O}, 0.8 \mathrm{~g} \mathrm{CuSO}_{4} \cdot 5 \mathrm{H}_{2} \mathrm{O}, 3 \mathrm{~g}$ $\mathrm{MnSO}_{4} \cdot \mathrm{H}_{2} \mathrm{O}, 5 \mathrm{~g} \mathrm{ZnSO}_{4} \cdot \mathrm{H}_{2} \mathrm{O}, 10 \mathrm{mg} \mathrm{Na} \mathrm{SeO}_{3}, 40 \mathrm{mg} \mathrm{KI}, 30 \mathrm{mg} \mathrm{CoCl}{ }^{2} \cdot 6 \mathrm{H}_{2} \mathrm{O}, 95000 \mathrm{IU}$ vitamin A, $17500 \mathrm{IU}$ vitamin $\mathrm{D}$, and $18000 \mathrm{IU}$ vitamin $\mathrm{E}$;

$\mathrm{ME}=$ metabolizable energy, calculated according to the data of Zhang \& Zhang (1998).

\subsection{Measurements and Sampling}

For the entire experimental period, the amounts of feed offered and orts collected prior to the feeding were recorded daily, and the daily feed intake was calculated. The kids were weighed on days 1,42 and 105 prior to the morning feeding and the weights were used to calculate the averaged daily body weight gains (BWG) over the periods of nutritional restriction and nutritional recovery respectively.

On d 42 (ie, the end of nutrient restriction) and d 105 (the end of nutrient recovery) of the experimental day, three kids with similar body weights from each group were anaesthetized with an intravenous injection of sodium pentobarbital $(50 \mathrm{mg} / \mathrm{kg} \mathrm{BW})$ and bled for exsanguinations, respectively. Then the abdominal cavity of the kid was opened, and the viscera were removed. The liver and spleen were separated and weighted. Liver sample (about $4 \mathrm{~g}$ ) at top right leaf, whole spleen and the longissimus dorsi between 8th and 12th ribs from right side were collected, immediately frozen in liquid $\mathrm{N}$ and stored at $-80^{\circ} \mathrm{C}$ for later analysis. 


\subsection{Analytical Procedures}

Samples of the feeds and orts were analyzed for dry matter (DM) and Kjeldahl $\mathrm{N}$ content (CP), calcium and phosphorus (AOAC, 1990).

Diphenylamine and orcinol procedures were used, respectively, to analyze for DNA and RNA concentrations (Scheaffer et al., 2004; Swanson et al., 1999). Type I DNA from calf thymus and type IV RNA from calf liver (Sigma-Aldrich, Oakville, Ontario, Canada) were used as standards. True protein concentration was determined by using the procedure of Lowry et al. (1951) with bovine serum albumin (BSA) as the standard. Total DNA, RNA, and protein contents were calculated by multiplying their concentrations in tissue with the fresh tissue weight. The concentration and content of DNA were used as an index of tissue hyperplasia (change in cell number), and RNA: DNA and protein: DNA ratios were used as indexes of tissue hypertrophy (change in cell size) (Baserga, 1985; Swanson et al., 1999).

The frozen tissues (about $1 \mathrm{~g}$ ) of liver, spleen and longissimus dorsi were homogenized in $0.9 \% \mathrm{NaCl}(9 \mathrm{~mL})$ with a polytron (Brinkmann Instruments Inc., Westbury, NY), centrifuged at 3, 000 $\times \mathrm{g}$ for $20 \mathrm{~min}$ at $4^{\circ} \mathrm{C}$, and the supernatant was collected and stored at $-80^{\circ} \mathrm{C}$ for antioxidation capacity analysis. The supernatant and plasma were used for the determination of GSH and malondialdehyde (MDA), the activities of catalase (CAT), SOD, glutathione peroxidase (GSH-Px) and glutathione reductase (GR) using colorimetric methods with a spectrophotometer (Biomate 5, Thermo Electron Corporation, Rochester, NY). The assays were conducted using the assay kits purchased from Nanjin Jianchen Institute of Bioengineering (Nanjing, China). The GSH content was measured spectrophotometrically with the procedures described by Sedlak \& Lindsay (1968). The MDA content was determined as an indicator of lipid peroxidation by recording formation of a spectrophotometrically detectable carbocyanine dye, which results from the reaction of MDA with N-methyl-2-phenylindole at $45^{\circ} \mathrm{C}$ (Gerard-Monnier et al., 1998). The CAT activity was determined spectrophotometrically according to the method of Goth (1991). The SOD activity was measured spectrophotometrically using the method of Flohe and Otting (1984). The GSH-Px activity was determined using the method described by Lawrence \& Burk (1976). The GR activity was determined by a procedure reported by Benson et al. (1980) after a slight modification.

The frozen liver, or spleen and longgissimus dorsi $(0.5 \mathrm{~g})$ were homogenized in $5 \mathrm{~mL}$ TRIzol reagent (Invitrogen) and total RNA were isolated according to the manufacturer's recommendations. The RNA integrity and quantity were analyzed using the Agilent 2100 Bioanalyzer and RNA 6000 Nano-LabChip kit (Agilent catalog no. $5065-4474$ ). The peak area ratio of $28 \mathrm{~S}$ ribosome to $18 \mathrm{~S}$ ribosome was $\geq 1.80$ for all samples, indicating little degradation of RNA.

Real-time PCR technology was employed to determine the mRNA level of SOD. The total RNA in a sample was reversely transcribed into cDNA by AMV First Strand cDNA Synthesis Kit (Bio Basic Inc. Canada, lot number: BS252). The RT-PCR analysis was performed using the SYBR Green method and the ABI 7900 Sequence Detection System (Applied Biosystems). Each PCR mixture, with a final volume of $20 \mu \mathrm{l}$, was composed of $10 \mu \mathrm{l}$ of SYBR PrimeScriptTM Mix (TaKaRa, Dalian, China), $100 \mathrm{nM}$ of each gene-specific primer as below, and $2 \mu 1$ cDNA in each reaction. The thermal cycling parameters were as follows: $94^{\circ} \mathrm{C}$ for $30 \mathrm{~s}$, followed by 40 cycles of $94^{\circ} \mathrm{C}$ for $5 \mathrm{~s}, 55^{\circ} \mathrm{C}$ for $20 \mathrm{~s}$ and $72^{\circ} \mathrm{C}$ for $20 \mathrm{~s}$. The primers for SOD (target gene) and glyceraldehydes-3-phosphate (GAPDH, endogenous and stable reference gene, Murthi et al. 2008) were designed by Primer Premier 5.0 according to the SOD gene (459-bp, GenBank accession number: AB201469.1) and GAPDH gene (570-bp the endogenous control, GenBank accession number: AJ431207.1) searched from Genbank (http://www.ncbi.nlm.nih.gov). Primers for goat SOD gene (Forword 5'- GGAGAT AAAGT CGTCG TAAC -3', reverse 5' TATCC ACAAT GGCAA CAC -3') and goat GAPDH gene (5'- GGGTC ATCAT CTCTG CACCT -3', reverse 5'- GGTCA TAAGT CCCTC CACGA -3') were synthesized by Shanghai Sangon Biological Engineering Technology \& Service Co Ltd (Shanghai, China). The lengths of PCR products of SOD and GAPDH were 220-bp and 176-bp respectively.

A melting curve analysis was conducted after amplification. Analyses were performed in triplicate, and the mean values were calculated. Data were collected and calculated using the fit point option of LightCycler software version 3.5. A calibration curve was generated by the amplification of serially diluted cDNA using the fit point option of the LightCycler software for the target genes and the GAPDH gene that was used as an internal control individually. The threshold fluorescence level was determined within the geometric region of the semilog view of the amplification plot. Relative expression of the target gene was calculated using the formula $2^{-\Delta \Delta \mathrm{Ct}}$ (Livak \& Schmittgen 2001), where the internal control gene was GAPDH.

\subsection{Statistical Analysis}

Data were analyzed using the General Linear Models procedure of SAS (2002). The results were subjected to the 
GLM procedure. The following model was used for the data analysis:

$$
Y_{i j k}=\mu+T_{i}+e_{i}
$$

Where $Y_{i j k}$ is the dependent variable, $\mu$ is the overall mean, $T_{i}$ is the fixed effect of treatment, and $e_{i}$ is the random residual error.

\section{Results}

\subsection{Intakes and Growth}

The results of feed intake and BWG have been presented in other papers (not published at present). However, the data of feed intake and BWG are important for present study, the authors simply state the information of feed intake and BWG here. There were no differences in intakes of the starter feed and ryegrass hay during a period of nutritional restriction among four groups $(\mathrm{P}>0.05)$. The actual intakes of $\mathrm{CP}$ in groups of control, $\mathrm{PR}$, ER and EPR were 34.9, 26.7, 36.6 and $26.6 \mathrm{~g} / \mathrm{d}$ respectively, and 35\% less in PR and EPR groups compared to the control; the corresponding ME intakes were 2.36, 1.90, 2.31 and $1.73 \mathrm{MJ} / \mathrm{d}$, and $20 \%$ less in ER and $36 \%$ less in EPR compared to the control. The same intakes of ryegrass among four groups reduced the magnitudes of protein and energy restriction, which was resulted from reduced concentrations of $\mathrm{CP}$ and $\mathrm{ME}$ of the starter feed for the nutritional restriction groups. During the period of nutrient recovery there were no differences in intakes of $\mathrm{CP}$ and $\mathrm{ME}$ among four groups $(\mathrm{P}>0.05)$. The $\mathrm{BWG}$ of kids in groups of $\mathrm{PR}$, ER and EPR during the periods of nutritional restriction and nutritional recovery were less than those of kids in control $(\mathrm{P}<0.001)$.

\subsection{Antioxidant Capacity}

The antioxidant capacity of tissues was presented in Table 2, Table 3 and Table 4. On d 42, when compared with control, energy restriction decreased the activity of GSH-Px in spleen, and the mRNA level of SOD in muscle and spleen $(\mathrm{P}<0.05)$; Protein restriction decreased the activity of GR in muscle and liver, the concentration of GSH in spleen, and the mRNA level of SOD in muscle and spleen $(\mathrm{P}<0.05)$; combined restriction of energy and protein decreased the activities of CAT and GR in muscle, GR in liver, and SOD, GSH-Px and GR in spleen, the GSH content in spleen, and the mRNA level of SOD in muscle and spleen $(\mathrm{P}<0.05)$. After nutrient recovery for nine weeks, there were no differences in antioxidant parameters determined in this study among four groups $(\mathrm{P}>$ 0.05).

Table 2. Effects of energy and/or protein restriction for six weeks on antioxidant capacity of muscle, liver and spleen of weaned kids (d 42)

\begin{tabular}{|c|c|c|c|c|c|c|}
\hline & \multicolumn{4}{|c|}{ Treatments ${ }^{I}$} & \multirow{2}{*}{ S.E.M. ${ }^{2}$} & \multirow{2}{*}{$P$-value } \\
\hline & Control & ER & PR & EPR & & \\
\hline \multicolumn{7}{|c|}{ Muscle } \\
\hline CAT (IU/mg protein) & $14.3^{\mathrm{a}}$ & $14.0^{\mathrm{a}}$ & $12.2^{\mathrm{ab}}$ & $10.6^{\mathrm{b}}$ & 0.69 & 0.015 \\
\hline MDA (nmol/mg protein) & 1.31 & 1.31 & 1.52 & 1.40 & 0.07 & 0.237 \\
\hline SOD (IU/mg protein) & 120 & 122 & 121 & 105 & 7.0 & 0.323 \\
\hline GSH-Px (IU/mg protein) & 45.7 & 43.2 & 45.9 & 42.5 & 2.76 & 0.769 \\
\hline $\mathrm{GSH}(\mathrm{mg} / \mathrm{g}$ protein) & 8.93 & 8.65 & 8.64 & 9.06 & 0.65 & 0.956 \\
\hline GR (IU/g protein) & \multicolumn{5}{|c|}{ Liver } & 0.019 \\
\hline CAT (IU/mg protein) & 1.63 & 1.64 & 1.63 & 1.52 & 0.06 & 0.529 \\
\hline $\mathrm{MDA}$ (nmol/mg protein) & 1.38 & 1.55 & 1.41 & 1.54 & 0.13 & 0.202 \\
\hline SOD (IU/mg protein) & 47.4 & 49.1 & 49.7 & 46.1 & 2.2 & 0.640 \\
\hline GSH-Px (IU/mg protein) & 14.3 & 13.0 & 14.3 & 13.1 & 0.96 & 0.302 \\
\hline GSH (mg/g protein) & 6.31 & 6.05 & 6.48 & 6.39 & 0.40 & 0.886 \\
\hline GR (IU/g protein) & $2.91^{\mathrm{a}}$ & $2.49^{\mathrm{ab}}$ & $1.90^{\mathrm{b}}$ & $1.23^{\mathrm{c}}$ & 0.18 & 0.001 \\
\hline \multicolumn{7}{|c|}{ Spleen } \\
\hline CAT (IU/mg protein) & 1.99 & 1.82 & 1.71 & 1.55 & 0.09 & 0.079 \\
\hline MDA (nmol/mg protein) & 1.74 & 1.78 & 1.72 & 1.80 & 0.10 & 0.830 \\
\hline SOD (IU/mg protein) & $36.2^{\mathrm{a}}$ & $32.7^{\mathrm{ab}}$ & $34.2^{\mathrm{ab}}$ & $30.4^{\mathrm{b}}$ & 1.2 & 0.043 \\
\hline GSH-Px (IU/mg protein) & $15.7^{\mathrm{a}}$ & $13.4^{\mathrm{b}}$ & $14.6^{\mathrm{ab}}$ & $13.0^{\mathrm{b}}$ & 0.52 & 0.040 \\
\hline $\mathrm{GSH}$ (mg/g protein) & $3.66^{\mathrm{a}}$ & $3.23^{\mathrm{ab}}$ & $2.62^{\mathrm{b}}$ & $2.36^{\mathrm{b}}$ & 0.16 & 0.001 \\
\hline GR (IU/g protein) & $3.40^{\mathrm{a}}$ & $3.10^{\mathrm{ab}}$ & $3.21^{\mathrm{ab}}$ & $2.59^{\mathrm{b}}$ & 0.17 & 0.047 \\
\hline
\end{tabular}

${ }^{a, b, c}$ Means in the same row not bearing a common superscript letter differ significantly $(\mathrm{P}<0.05)$;

$\mathrm{ER}=$ energy restriction; $\mathrm{PR}=$ protein restriction; $\mathrm{EPR}=$ combination energy and protein restriction;

S.E.M. $=$ standard error of means; 
Table 3. Effects of energy and/or protein restriction for six weeks on antioxidant capacity of muscle, liver and spleen of weaned kids (d 105)

\begin{tabular}{|c|c|c|c|c|c|c|}
\hline & \multicolumn{4}{|c|}{ Treatments } & \multirow{2}{*}{ S.E.M. ${ }^{2}$} & \multirow{2}{*}{$P$-value } \\
\hline & Control & ER & PR & LEP & & \\
\hline \multicolumn{7}{|c|}{ Muscle } \\
\hline CAT (IU/mg protein) & 13.2 & 13.7 & 12.5 & 12.5 & 0.88 & 0.327 \\
\hline MDA (nmol/mg protein) & 2.05 & 1.99 & 1.85 & 2.10 & 0.11 & 0.461 \\
\hline SOD (IU/mg protein) & 139 & 140 & 129 & 121 & 6.8 & 0.235 \\
\hline GSH-Px (IU/mg protein) & 46.7 & 47.0 & 49.0 & 41.1 & 3.15 & 0.386 \\
\hline GSH (mg/g protein) & 9.20 & 8.83 & 8.31 & 8.27 & 0.65 & 0.715 \\
\hline GR (IU/g protein) & 6.66 & 7.49 & 6.82 & 6.93 & 0.50 & 0.361 \\
\hline \multicolumn{7}{|c|}{ Liver } \\
\hline CAT (IU/mg protein) & 1.94 & 1.86 & 1.85 & 1.83 & 0.10 & 0.895 \\
\hline MDA (nmol/mg protein) & 0.88 & 0.98 & 1.01 & 1.08 & 0.06 & 0.243 \\
\hline SOD (IU/mg protein) & 55.3 & 58.3 & 56.3 & 55.7 & 4.2 & 0.959 \\
\hline GSH-Px (IU/mg protein) & 16.8 & 15.9 & 14.8 & 15.2 & 0.82 & 0.385 \\
\hline GSH (mg/g protein) & 7.14 & 7.13 & 7.40 & 7.35 & 0.37 & 0.934 \\
\hline GR (IU/g protein) & 3.26 & 3.62 & 3.46 & 2.60 & 0.35 & 0.573 \\
\hline \multicolumn{7}{|c|}{ Spleen } \\
\hline CAT (IU/mg protein) & 2.37 & 2.08 & 2.10 & 2.36 & 0.14 & 0.150 \\
\hline MDA (nmol/mg protein) & 1.71 & 1.88 & 1.93 & 2.25 & 0.15 & 0.156 \\
\hline SOD (IU/mg protein) & 40.9 & 39.1 & 41.7 & 37.6 & 2.1 & 0.203 \\
\hline GSH-Px (IU/mg protein) & 18.7 & 16.8 & 18.5 & 17.0 & 1.0 & 0.191 \\
\hline GSH (mg/g protein) & 3.14 & 3.05 & 3.40 & 2.70 & 0.44 & 0.332 \\
\hline GR (IU/g protein) & 3.82 & 3.73 & 3.85 & 3.36 & 0.32 & 0.442 \\
\hline
\end{tabular}

a,b,c Means in the same row not bearing a common superscript letter differ significantly $(\mathrm{P}<0.05)$;

$\mathrm{ER}=$ energy restriction; $\mathrm{PR}=$ protein restriction; $\mathrm{EPR}=$ combination energy and protein restriction;

S.E.M. $=$ standard error of means.

Table 4. Effects of energy and/or protein restriction for six weeks on SOD gene expression of muscle, liver and spleen of kids (calculated using $2^{-\Delta \Delta \mathrm{Ct}}$ method)

\begin{tabular}{|c|c|c|c|c|c|c|}
\hline & \multicolumn{4}{|c|}{ Treatments ${ }^{1}$} & \multirow{2}{*}{ S.E.M. ${ }^{2}$} & \multirow{2}{*}{$P$-value } \\
\hline & Control & ER & $\overline{P R}$ & EPR & & \\
\hline \multicolumn{7}{|c|}{ D 42} \\
\hline Muscle & $2.68^{\mathrm{a}}$ & $1.52^{\mathrm{b}}$ & $1.51^{\mathrm{b}}$ & $1.38^{\mathrm{b}}$ & 0.29 & 0.047 \\
\hline Liver & 2.03 & 1.69 & 1.98 & 1.63 & 0.42 & 0.611 \\
\hline Spleen & $2.89^{\mathrm{a}}$ & $1.11^{\mathrm{b}}$ & $1.46^{\mathrm{b}}$ & $1.50^{\mathrm{b}}$ & 0.33 & 0.024 \\
\hline \multicolumn{7}{|c|}{ D 105} \\
\hline Muscle & 1.08 & 1.03 & 0.92 & 1.02 & 0.07 & 0.337 \\
\hline Liver & 1.02 & 0.83 & 0.98 & 1.15 & 0.10 & 0.239 \\
\hline Spleen & 1.16 & 0.85 & 0.95 & 1.08 & 0.10 & 0.237 \\
\hline
\end{tabular}

${ }^{\mathrm{a}, \mathrm{b}, \mathrm{c}}$ Means in the same row not bearing a common superscript letter differ significantly $(\mathrm{P}<0.05)$;

$\mathrm{ER}=$ energy restriction; $\mathrm{PR}=$ protein restriction; $\mathrm{EPR}=$ combination energy and protein restriction;

S.E.M. $=$ standard error of means.

\subsection{Growth of Liver and Spleen}

As Table 5 shows, six weeks of energy restriction, protein restriction, and combined restriction of protein and energy decreased the weight of liver and spleen of kids $(P<0.05)$. After nutrient recovery for nine weeks, the weights of liver and spleen of kids in pre-protein restriction and pre-combined restriction of energy and protein 
restriction were still less than those of kids in control $(\mathrm{P}<0.05)$.

Table 5. Effects of energy and/or protein restriction for six weeks on the growth of liver and spleen of weaned kids

\begin{tabular}{|c|c|c|c|c|c|c|}
\hline & \multicolumn{4}{|c|}{ Treatments ${ }^{1}$} & \multirow{2}{*}{ s.e.m. } & \multirow{2}{*}{$P$-value } \\
\hline & Control & ER & PR & EPR & & \\
\hline $\begin{array}{c}\text { Weight of liver and spl } \\
\text { Day } 42\end{array}$ & & & & & & \\
\hline Spleen weight (g) & $7.43^{\mathrm{a}}$ & $5.73^{\circ}$ & $5.73^{\circ}$ & $5.53^{\mathrm{D}}$ & 0.13 & $<0.001$ \\
\hline $\begin{array}{l}\text { Liver weight (g) } \\
\text { Day } 105\end{array}$ & $123^{\mathrm{a}}$ & $101^{\mathrm{D}}$ & $101^{\mathrm{D}}$ & $97.0^{\mathrm{b}}$ & 2.19 & $<0.001$ \\
\hline Spleen weight (g) & $10.9^{\mathrm{a}}$ & $10.2^{\mathrm{ab}}$ & $9.96^{\mathrm{D}}$ & $9.52^{\circ}$ & 0.26 & 0.028 \\
\hline Liver weight (g) & $147^{\mathrm{a}}$ & $137^{\text {av }}$ & $132^{\circ}$ & $130^{\mathrm{D}}$ & 4.2 & 0.027 \\
\hline
\end{tabular}

a,b,c Means in the same row not bearing a common superscript letter differ significantly $(\mathrm{P}<0.05)$.

$\mathrm{ER}=$ energy restriction; $\mathrm{PR}=$ protein restriction; $\mathrm{EPR}=$ combination energy and protein restriction.

S.E.M. = standard error of means.

\subsection{The Concentrations of DNA, RNA and Protein}

The effects of protein and/or energy restriction for six weeks on concentrations of N, DNA and RNA of the muscle, liver and spleen of kids are presented in Table 6. Energy restriction decreased the ratio of RNA to DNA in liver $(\mathrm{P}<0.05)$, protein restriction decreased the ratio of RNA to DNA in liver, and the concentration of $\mathrm{N}$ and the ratio of $\mathrm{N}$ to DNA in spleen and muscle $(\mathrm{P}<0.05)$, and combined restriction of energy and protein decreased the ratio of RNA to DNA in liver, and the concentration of $\mathrm{N}$ and the ratio of $\mathrm{N}$ to DNA in spleen and muscle (P $<0.05)$. After nutritional recovery for nine weeks, the $\mathrm{N}$ content in liver of kids in PR and EPR, and the ratio of $\mathrm{N}$ to DNA in liver and spleen of kids in EPR were greater than those of kids in control $(\mathrm{P}<0.05)$, however the ratio of $\mathrm{N}$ to DNA of kids in EPR was still less than that of kids in control.

Table 6. Effects of energy and/or protein restriction for six weeks the concentrations of N, DNA and RNA, and the ratios of $\mathrm{N}$ to DNA and RNA to DNA of liver and spleen of weaned kids (d 42)

\begin{tabular}{|c|c|c|c|c|c|c|}
\hline \multirow[b]{2}{*}{ Items } & \multicolumn{4}{|c|}{ Treatments ${ }^{1}$} & \multirow{2}{*}{ s.e.m. ${ }^{2}$} & \multirow{2}{*}{ P-value } \\
\hline & Control & ER & PR & EPR & & \\
\hline \multicolumn{7}{|c|}{ Liver } \\
\hline $\mathrm{N}, \mathrm{mg} / \mathrm{g}$ tissue & 132 & 122 & 119 & 119 & 4.15 & 0.169 \\
\hline $\mathrm{DNA}, \mathrm{mg} / \mathrm{g}$ tissue & 21.6 & 21.5 & 20.7 & 21.2 & 0.54 & 0.738 \\
\hline RNA, mg/g tissue & 25.2 & 22.6 & 24.3 & 22.1 & 0.64 & 0.067 \\
\hline $\mathrm{N}$ : DNA & 6.13 & 5.70 & 5.75 & 5.62 & 0.29 & 0.612 \\
\hline RNA: DNA & $1.17^{\mathrm{a}}$ & $1.05^{\mathrm{D}}$ & $1.07^{\mathrm{D}}$ & $1.04^{\mathrm{D}}$ & 0.03 & 0.045 \\
\hline \multicolumn{7}{|c|}{ Spleen } \\
\hline $\mathrm{N}, \mathrm{mg} / \mathrm{g}$ tissue & $122^{\mathrm{a}}$ & $116^{\mathrm{ab}}$ & $117^{\mathrm{oc}}$ & $103^{c}$ & 3.54 & 0.020 \\
\hline DNA, $\mathrm{mg} / \mathrm{g}$ tissue & 30.3 & 30.0 & 29.7 & 29.9 & 0.38 & 0.739 \\
\hline $\mathrm{RNA}, \mathrm{mg} / \mathrm{g}$ tissue & 25.6 & 25.7 & 24.7 & 24.5 & 1.18 & 0.829 \\
\hline $\mathrm{N}$ : DNA & $4.04^{\mathrm{a}}$ & $3.86^{\mathrm{ab}}$ & $3.47^{\circ}$ & $3.58^{\circ}$ & 0.11 & 0.029 \\
\hline RNA: DNA & 0.85 & 0.86 & 0.83 & 0.82 & 0.04 & 0.866 \\
\hline \multicolumn{7}{|c|}{ Muscle } \\
\hline $\mathrm{N}, \mathrm{mg} / \mathrm{g}$ tissue & $149^{\mathrm{a}}$ & $142^{\mathrm{ab}}$ & $126^{\mathrm{c}}$ & $131^{\mathrm{bc}}$ & 4.3 & 0.020 \\
\hline DNA, mg/g tissue & 46.6 & 45.5 & 46.5 & 45.3 & 0.53 & 0.284 \\
\hline RNA, mg/g tissue & 36.1 & 33.7 & 31.9 & 31.7 & 1.74 & 0.309 \\
\hline $\mathrm{N}$ : DNA & $3.20^{\mathrm{a}}$ & $3.12^{\mathrm{av}}$ & $2.71^{\mathrm{c}}$ & $2.89^{\mathrm{bc}}$ & 0.09 & 0.016 \\
\hline RNA: DNA & 0.77 & 0.74 & 0.69 & 0.70 & 0.04 & 0.378 \\
\hline
\end{tabular}

${ }^{\mathrm{a}, \mathrm{b}, \mathrm{c}}$ Means in the same row not bearing a common superscript letter differ significantly $(\mathrm{P}<0.05)$;

$\mathrm{ER}=$ energy restriction; $\mathrm{PR}=$ protein restriction; $\mathrm{EPR}=$ combination energy and protein restriction;

S.E.M. = standard error of means. 
Table 7. Effects of energy and/or protein restriction for six weeks the concentrations of N, DNA and RNA, and the ratios of $\mathrm{N}$ to DNA and RNA to DNA of liver and spleen of weaned kids (d 105)

\begin{tabular}{|c|c|c|c|c|c|c|}
\hline & \multicolumn{4}{|c|}{ Treatments $^{1}$} & \multirow{2}{*}{ s.e.m. ${ }^{2}$} & \multirow{2}{*}{ P-value } \\
\hline & Control & ER & PR & EPR & & \\
\hline \multicolumn{7}{|c|}{ Liver } \\
\hline $\mathrm{N}, \mathrm{mg} / \mathrm{g}$ tissue & $122^{\mathrm{c}}$ & $128^{\mathrm{bc}}$ & $131^{\mathrm{ab}}$ & $139^{\mathrm{a}}$ & 2.4 & 0.008 \\
\hline DNA, mg/g tissue & 17.7 & 17.4 & 17.4 & 18.1 & 0.59 & 0.831 \\
\hline RNA, mg/g tissue & 15.8 & 16.5 & 16.4 & 17.3 & 0.39 & 0.068 \\
\hline $\mathrm{N}$ : DNA & $6.95^{\mathrm{b}}$ & $7.33^{\mathrm{ab}}$ & $7.53^{\mathrm{a}}$ & $7.66^{\mathrm{a}}$ & 0.14 & 0.048 \\
\hline RNA: DNA & 0.90 & 0.95 & 0.94 & 0.95 & 0.04 & 0.744 \\
\hline $\mathrm{N}, \mathrm{mg} / \mathrm{g}$ tissue & 125 & 131 & 132 & 137 & 3.6 & 0.218 \\
\hline \multicolumn{7}{|c|}{ Spleen } \\
\hline $\mathrm{N}, \mathrm{mg} / \mathrm{g}$ tissue & 124 & 131 & 132 & 136 & 3.6 & 0.217 \\
\hline DNA, $\mathrm{mg} / \mathrm{g}$ tissue & 27.8 & 28.0 & 28.5 & 26.7 & 0.60 & 0.297 \\
\hline RNA, mg/g tissue & 28.8 & 30.0 & 29.8 & 32.4 & 2.0 & 0.650 \\
\hline $\mathrm{N}$ : DNA & $4.47^{\mathrm{b}}$ & $4.67^{\mathrm{b}}$ & $4.63^{\mathrm{b}}$ & $5.10^{\mathrm{a}}$ & 0.08 & 0.004 \\
\hline RNA: DNA & 0.97 & 0.94 & 0.96 & 0.84 & 0.07 & 0.326 \\
\hline \multicolumn{7}{|c|}{ Muscle } \\
\hline $\mathrm{N}, \mathrm{mg} / \mathrm{g}$ tissue & 142 & 136 & 137 & 129 & 3.8 & 0.217 \\
\hline DNA, $\mathrm{mg} / \mathrm{g}$ tissue & 36.8 & 38.5 & 39.2 & 38.3 & 0.82 & 0.296 \\
\hline RNA, mg/g tissue & 47.8 & 44.2 & 43.8 & 42.3 & 2.9 & 0.650 \\
\hline $\mathrm{N}$ : DNA & $3.85^{\mathrm{a}}$ & $3.73^{\mathrm{ab}}$ & $3.74^{\mathrm{ab}}$ & $3.48^{\mathrm{b}}$ & 0.16 & 0.033 \\
\hline RNA: DNA & 0.78 & 0.88 & 0.90 & 0.91 & 0.07 & 0.307 \\
\hline
\end{tabular}

${ }^{\mathrm{a}, \mathrm{b}, \mathrm{c}}$ Means in the same row not bearing a common superscript letter differ significantly $(\mathrm{P}<0.05)$;

$\mathrm{ER}=$ energy restriction; $\mathrm{PR}=$ protein restriction; $\mathrm{EPR}=$ combination energy and protein restriction;

S.E.M. = standard error of means.

\section{Discussion}

\subsection{Growth of Tissues}

We found in this study that protein and/or energy restriction for six weeks substantially reduced the weights of the liver and spleen of weaned kids. Previous studies have demonstrated similar results (Yeh, 1983; Johnson et al., 1990; Sainz \& Bentley, 1997; McLeod \& Baldwin, 2000; D'Inca et al., 2010; Wang et al., 2005).

We also found the retardation of liver and spleen, which was resulted from the protein and/or energy restriction for six weeks, continued during the period of nutritional recovery for nine weeks. However, the ratios of spleen weight of kids in ER, PR and EPR to spleen weight of kids in control, which were $77.1 \%, 77.1 \%$ and $74.4 \%$ by d 42 , were increased to $93.5 \%, 91.3 \%$ and 87.3 by d 105 respectively. Also, the ratios of spleen weight of kids in ER, PR and EPR to spleen weight of kids in control, which were $82.1 \%, 82.1 \%$ and $78.8 \%$ by d 42 , were increased to $93.2 \%, 89.8 \%$ and $88.4 \%$ by d 105 respectively. The muscle weighs of kids on d 42 and d 105 were not determined in this study. Therefore, the ratios of muscle weight of kids in ER, PR and EPR to the muscle weight of kids in control cannot be gained. The results indicate that when the kids in poor nutritional status got the adequate nutrient supplies, the liver and spleen grew faster than the kids under good nutritional status. The ratios of BWG of kids in ER, PR and EPR to the BWG of kids in control, were $80.8 \%, 75.5 \%$ and $60.1 \%$ by $\mathrm{d} 42$, and decreased to $77.7 \%, 72.2 \%$ and $58.1 \%$ by $\mathrm{d} 105$. The results also suggest that during the compensatory growth period, there is a differentiation in the growth between liver and spleen organs and the rest of the body.

\subsection{The Concentrations of DNA, RNA and Protein in Tissues}

The current experiment demonstrated that six weeks of energy and/or protein restriction did not affect the concentrations of DNA and RNA in the muscle, liver and spleen. However, the substantial changes in the protein concentrations in response to nutritional restriction and nutritional recovery were observed. The concentration of DNA is usually used as an index for tissue hyperplasia (increase in cell number), and the ratios of RNA to DNA and protein to DNA are used as an index for tissue hypertrophy (increase in cell size) (Baserga, 1985; Swanson et al., 1999). Therefore, the changes in ratios of $\mathrm{N}$ to DNA or RNA to DNA could indicate that the effects of energy and protein or combined energy and protein restriction on the development of muscle, liver and spleen of weaned kids were largely accompanied by changes in cellular enlargement (hypertrophy) or protein synthetic 
capacity. After nutritional recovery for nine weeks, the ratio of $\mathrm{N}$ to DNA ratio in liver of kids in PR and EPR and the ratio of $\mathrm{N}$ to DNA ratio in spleen of kids in EPR were greater than those of kids in control, and the indicate that ratio of $\mathrm{N}$ to DNA in muscle was still less than that of kids in control. The results indicate that liver and spleen showed faster differential growth in relevance to muscle during the compensatory growth period, mainly attributed to cellular enlargement (hypertrophy).

\subsection{The Antioxidant Capacity in Tissues}

Although meat ruminant extensive systems can increase the reproductive and productive performance of the head, abrupt weaning is a source of stress for the animals (Lynch et al., 2010; Ungerfeld et al., 2011; Enríquez et al., 2010). Generally, weaning causes a wide range of physiological and behavioural responses (Hickey et al., 2003; Loberg et al., 2008; Carroll et al., 2009). After weaning, the concentrations of glutamine, vitamin $\mathrm{E}$ and vitamin A in blood were declined (Lauridsen \& Jensen, 2005; Dobrowolski \& Śliwa, 2008; Petrovič et al., 2009). Therefore, the antioxidant capacity of animals after weaning is generally decreased. Nieto et al. (2000) and Burke et al. (2009) also observed that weaning decreased the antioxidant capacity and increased free radicals.

The nutritionally imbalanced diet provided to early weaned animals more easily lead to decrease of the antioxidant capacity, and further lead to oxidative stress generation. Because the antioxidation defense network of animals against oxygen free radicals is composed of endogenous (e.g., SOD, GSH, GSH-Px, GR and CAT) and dietary factors (e.g., vitamin $\mathrm{E}$ and selenium) that act in a dynamic interrelationship, including complex sparing and recycling reactions that allow for quenching a variety of reactive species and also conserving elements of the network itself (Fang et al., 2002). In this study, protein restriction or combined energy and protein restriction to kids for six weeks caused the decreases in activity or content of the endogenous antioxidants in muscle, liver and muscle. Previous studies have observed similar results in muscle, liver, muscle or other tissues and organs (Nozik et al., 2005; Akinola et al., 2010). It is well known that the principal defense systems against oxygen free radicals are SOD, GSH, GSH-Px, GR, CAT and antioxidant nutrients, e.g., vitamin $\mathrm{E}$ and selenium, which can catalyze the decomposition of oxidants and free radicals (Fang et al., 2002). The results in present study indicate that the antioxidant capacity of muscle, liver and spleen of weaned kids was reduced by energy and/or protein restrictions. The decrease in the antioxidant capacity caused by the nutrient deficiency was likely to result in the accumulation of free radicals in muscle, liver and spleen. As containing an iron-sulfur center, the accumulation of free radicals in muscle, liver and spleen would cause the oxidation of bio-molecules (e.g., protein, amino acids, lipid and DNA), which further lead to cell injury and death (Adams \& Odunze, 1991; Bachowski et al., 1997). This may be one of the main reasons for the growth retardation of liver, spleen and muscle of kids in energy and/or protein restriction groups.

What could be the reasons for the decrease of endogenous antioxidation factors in activity or content caused by protein deficiency? It is well known that protein (amino acids) has major importance as a source of amino acids and essential nutrients, being the precursor of neurotransmitters, structural proteins, enzymes and other vital proteins (Siegel, 1999). Methionine deficiency affects the biosynthesis of proteins not merely due to the lack of this amino acid in protein chains, but it is also fundamental for the initiation of protein synthesis in ribosomes. Methionine is also necessary for the synthesis of GSH, which has an important function being as a substrate for detoxification enzymes (Griffith, 1999; Li et al., 2002). Glutamine (Gln) is the most abundant free amino acid in the circulation. Gln is the precursor for the synthesis of GSH. There is a significant correlation between Gln supply and intracellular GSH content (Roth et al., 2002). There is increasing evidence that Gln supplementation enhances antioxidant capacity (Alves et al., 2010; Das et al., 2007; Tsai et al., 2012). Other amino acids (e.g., arginine, citrulline, glycine, taurine and histidine), small peptides (e.g., GSH and carnosine), and nitrogenous metabolites (e.g., creatine and uric acid) directly scavenge oxygen free radicals (Fang et al., 2002). Thus, dietary deficiency of protein not only impairs the synthesis of antioxidant enzymes but also reduces tissue concentrations of antioxidants (Sies, 1999).

The previous studies have proven that energy restriction can increase longevity though reduction in production of reactive oxygen species (ROS) and subsequent oxidative damage to cells (Sohal \& Weindruch, 1996; Lass et al., 1998; Sreekumur et al., 2002; Heilbronn et al., 2006). The results in the present study seemed to be not consistent with the previous findings about effects of energy restriction on antioxidant capacity. However, the animal or human in above studies are all adults, the experimental animal in the present study was weaned kids. Thereby, it may be concluded that energy deficiency during the critical period of development would reduce antioxidant capacity of muscle, liver and spleen. However, the hypothesis needs further validation.

In the whole, the results of this study indicate that six weeks of energy and/or protein restriction reduced the antioxidant capacity of liver, spleen and muscle of weaned kids, and inhibited the development of liver, spleen 
and muscle though changing cellular enlargement (hypertrophy). After a period of 9 weeks of nutritional recovery, the reduction of antioxidation capacity in the muscle, liver and spleen were fully retrieved, and compensatory growth, which was mainly hypertrophic, was exhibited in the development of liver and spleen of kids.

\section{References}

Adams, J. D., \& Odunze, I. N. (1991). Oxygen free-radicals and parkinsons-disease. Free Radical Biology and Medicine, 10, 161-169. http://dx.doi.org/10.1016/0891-5849(91)90009-R

Aguilera, A., Bajo, M. A., Espinoza, M., Olveira, A., Paiva, A. M., Codoceo, R., Garcia, P., ... Selgas, R. (2003). Gastrointestinal and pancreatic function in peritoneal dialysis patients: Their relationship with malnutrition and peritoneal membrane abnormalities. American Journal of Kidney Diseases, 42, 787-796. http://dx.doi.org/10.1016/S0272-6386(03)00920-X

Akinola, F. F., Oguntibeju, O. O., \& Alabi, O. O. (2010). Effects of severe malnutrition on oxidative stress in Wistar rats. Scientific Research and Essays, 5, 1145-1149. Retrieved from http://www.academicjournals.org/SRE

Alves, W. F., Aguiar, E. E., Guimarães, S. B., da Silva Filho, A. R., Pinheiro, P. M., Soares Gdos, S., \& de Vasconcelos, P. R. (2010). L-Alanylglutamine preoperative infusion in patients with critical limb ischemia subjected to distal revascularization reduces tissue damage and protects from oxidative stress. Annals of Vascular Surgery, 24, 461-467. http://dx.doi.org/10.1016/j.avsg.2010.01.005

AOAC. (1990). Official Methods of Analysis.(15th edn). Washingto, DC: AOAC.

Bachowski, S., Kolaja, K. L., Ketcham, C. A., Stevenson, D. E., Walborg, E. F., \& Klaunig, J. E. (1997). Role of oxidative stress in the mechanism of dieldrin's hepatotoxicity. Annals of Clinical and Laboratory Science, 27, 196-209. Retrieved from http://www.annclinlabsci.org/content/27/3/196.abstract

Baserga, R. (1985). The biology of cell reproduction. Cambridge, MA: Harvard University Press.

Benson, A. M., Hunkeler, M. J., \& Talalay, P. (1980). Increase of NAD(P)H: quinone reductase by dietary antioxidants: possible role in protection against carcinogenesis and toxicity. Proceedings of the National Academy of Sciences of the United States of America, 77, 5216-5220. Retrieved from http://www.ncbi.nlm.nih.gov/pmc/articles/PMC350028/pdf/pnas00496-0199.pdf

Burke, N. C., Scaglia, G., Boland, H. T., \& Swecker, W. S. (2009). Influence of two-stage weaning with subsequent transport on body weight, plasma lipid peroxidation, plasma selenium, and on leukocyte glutathione peroxidase and glutathione reductase activity in beef calves. Veterinary Immunology and Immunopathology, 127, 365-370. http://dx.doi.org/10.1016/j.vetimm.2008.11.017

Carroll, J. A., Arthington, J. D., \& Chase, C. C. (2009). Early weaning alters the acute phase reaction to an endotoxin challenge in beef calves. Journal of Animal Science, 87, 4167-4172. http://dx.doi.org/10.2527/jas.2009-2016

Das, S., Kar Mahapatra, S., Gautam, N., Das, A., \& Roy, S. (2007). Oxidative stress in lymphocytes, neutrophils, and serum of oral cavity cancer patients: modulatory array of L-glutamine. Supportive Care in Cancer, 15, 1399-1405. http://dx.doi.org/ 10.1007/s00520-007-0266-3

D'Inca, R., Kloareg, M., Gras-Le Guen, C., \& Le Huerou-Luron, I. (2010). Intrauterine growth restriction modifies the developmental pattern of intestinal structure, transcriptomic profile, and bacterial colonization in neonatal pigs. Journal of Nutrition, 140, 925-931. http://dx.doi.org/ 10.3945/jn.109.116822

Dobrowolski, P., \& Śliwa, E. (2008). The weaning-related changes in amino acids status of blood plasma in piglets. Journal of Pre-Clinical and Clinical Research, 2, 071-074. Retrieved from: http://jpccr.eu/search.php

Enríquez, D. H., Ungerfeld, R., Quintans, G., Guidoni, A. L., \& Hötzel, M. J. (2010). The effects of alternative weaning methods on behaviour in beef calves. Livestock Science, 128, 20-27. http://dx.doi.org/10.1016/j.livsci.2009.10.007

Fabian, J., Chiba, L. I., Frobish, L. T., McElhenney, W. H., Kuhlers, D. L., \& Nadarajah, K. (2004). Compensatory growth and nitrogen balance in grower-finisher pigs. Journal of Animal Science, 82, 2579-2587. Retrieved from $\mathrm{http}: / /$ jas.fass.org/content/82/9/2579

Fang, Y. Z., Yang, S., \& Wu, G. Y. (2002). Free radicals, antioxidants, and nutrition. Nutrition, 18, 872-879. http://dx.doi.org/10.1016/S0899-9007(02)00916-4 
Flohe, L.,, \& Otting, F. (1984). Superoxide dismutase assay. Methods in Enzymology, 195, 93-104. http://dx.doi.org/10.1016/S0076-6879(84)05013-8

Fukuda, M. T. H., Francolin-Silva, A. L., \& Almeida, S. S. (2002). Early postnatal protein malnutrition affects learning and memory in the distal but not in the proximal cue version of the Morris water maze. Behavioural Brain Research, 133, 271-277. http://dx.doi.org/10.1016/S0166-4328(02)00010-4

Gerard-Monnier, D., Erdelmeier, I., Chaudiere, J., \& Yadan, J. C. (1998). Method of colorimetric analysis of malonic dialdehyde and 4-hydroxy-2-enaldehydes as indexes of lipid peroxidation, kits for carrying out said method, substituted indoles for use in said method and their preparation. US Patent No. US5726063. United States Patent and Trademark Office, Washington, DC.

Goth, L. (1991). A simple method for determination of serum catalase activity and revision of reference range. Clinica Chimica Acta, 196, 143-151. http://dx.doi.org/10.1016/0009-8981(91)90067-M

Griffith, O. W. (1999). Biologic and pharmacologic regulation of mammalian glutathione synthesis. Free Radical Biology and Medicine, 27, 922-935. http://dx.doi.org/10.1016/S0891-5849(99)00176-8

Heilbronn, L. K., de Jonge, L., Frisard, M. I., De Lany, J. P., Larson-Meyer, D. E., Rood, J., ... Pennington, C. T. (2006). Effect of 6-month calorie restriction on biomarkers of longevity, metabolic adaptation, and oxidative stress in overweight individuals-A randomized controlled trial. Journal of the American Medical Association, 295, 1539-1548. http://dx.doi.org/10.1001/jama.295.13.1539

Heyer, A., \& Lebret, B. (2007). Compensatory growth response in pigs: Effects on growth performance, composition of weight gain at carcass and muscle levels, and meat quality. Journal of Animal Science, 85, 769-778. http://dx.doi.org/ 10.2527/jas.2006-164

Hickey, M. C., Drennan, M., \& Earley, B. (2003). The effect of abrupt weaning of suckler calves on the plasma concentrations of cortisol, catecholamines, leukocytes, acute-phase proteins and in vitro interferon-gamma production. Journal of Animal Science, 81, 2847-2855. Retrieved from http://jas.fass.org/content/81/11/2847.full.pdf + html

Johnson, D. E., Johnson, K. A., \& Baldwin, R. L. (1990). Changes in liver and gastrointestinal-tract energy demands in response to physiological workload in ruminants. Journal of Nutrition, 120, 649-655. Retrieved from: http://jn.nutrition.org/content/120/6/649.full.pdf + html

Lass, A., Sohal, B. H., Weindruch, R., Forster, M. J., \& Sohal, R. S. (1998). Caloric restriction prevents age-associated accrual of oxidative damage to mouse skeletal muscle mitochondria. Free Radical Biology and Medicine, 25, 1089-1097. http://dx.doi.org/10.1016/S0891-5849(98)00144-0

Lauridsen, C., \& Jensen, S. K. (2005). Influence of supplementation of all-rac-tocopheryl acetate preweaning and vitamin C postweaning on alpha-tocopherol and immune responses of piglets. Journal of Animal Science, 83, 1274-1286. Retrieved from http://jas.fass.org/content/83/6/1274.full.pdf $+\mathrm{html}$

Lawrence, R. A., \& Burk, R. F. (1976). Glutathione peroxidase activity in selenium-deficient rat liver. Biochemical and Biophysical Research Communications, 71, 952-958. http://dx.doi.org/10.1016/0006-291X(76)90747-6

Li, J., Wang, H., Stoner, G. D., \& Bray, T. M. (2002). Dietary supplementation with cysteine prodrugs selectively restores tissue glutathione levels and redox status in protein-malnourished mice. Journal of Nutritional Biochemistry, 13, 625-633. http://dx.doi.org/10.1016/S0955-2863(02)00218-8

Li, W., Shi, Y. H., \& Yang, R. L. (2010). Reactive oxygen species serve as signals mediating glucose-stimulated somatostatin secretion from cultured rat gastric primary D-cells. Free Radical Research, 44, 614-623. http://dx.doi.org/10.3109/10715761003713549

Livak, K. J., \& Schmittgen, T. W. (2001). Analysis of relative gene expression data using real-time quantitative PCR and the $2^{-\Delta \Delta \mathrm{Ct}}$ method. Methods, 25, 402-408. http://dx.doi.org/10.1006/meth.2001.1262

Loberg, J. M., Hernandez, C. E., Thierfelder, T., Jensen, M. B., Berg, C. \& Lidfors, L. (2008). Weaning and separation in two steps-A way to decrease stress in dairy calves suckled by foster cows. Applied Animal Behaviour Science, 111, 222-234. http://dx.doi.org/10.1016/j.applanim.2007.06.011

Lowry, O. H., Rosebrough, N. J., Farr, A. L., \& Randall, R. J. (1951). Protein measurement with the folin phenol reagent. Journal of biological chemistry, 193, 265-275. Retrieved from: http://www.jbc.org/content/193/1/265.long

Lu, D. X., Zhang, P. Y., \& Wang, X. M. (1996). Scientific Technology of Feeding Goat. Chinese Beijing: 
Agriculture Press.

Lynch, E., Earley, B., McGee, M., \& Doyle, S. (2010). Characterisation of physiological and immunological responses in beef cows to abrupt weaning and subsequent housing. BMC Veterinary Research, 6, 37. http://dx.doi.org/10.1186/1746-6148-6-37

Marks, D. B., Marks, A. D., \& Smith, C. M. (1996). Basic Medical Biochemistry: A Clinical Approach. New York: Lippincott Williams \& Wilkins.

McLeod, K. R., \& Baldwin, R. L. (2000). Effects of diet forage : Concentrate ratio and metabolizable energy intake on visceral organ growth and in vitro oxidative capacity of gut tissues in sheep. Journal of Animal Science, 78, 760-770. Retrieved from http://jas.fass.org/content/78/3/760

Murthi, P., Fitzpatrick, E., Borg, A. J., Donath, S., Brennecke, S. P., \& Kalionis, B. (2008). GAPDH, 18S rRNA and YWHAZ are suitable endogenous reference genes for relative gene expression studies in placental tissues from human idiopathic fetal growth restriction. Placenta, 29, 798-801. http://dx.doi.org/10.1016/j.placenta.2008.06.007

Nieto, N., López-Pedrosa, J. M., Mesa, M. D., Torres, M. I., Fernández, M. I., Ríos, A., ... Gil, A. (2000). Chronic diarrhea impairs intestinal antioxidant defense system in rats at weaning. Digestive Diseases and Sciences, 45, 2044-2050. http://dx.doi.org/10.1023/A:1005603019800

Nozik, G. E., Suliman, H., \& Piantadosi, C. (2005). Extracellular superoxide dismutase. International Journal of Biochemistry, 37, 2466-2471. http://dx.doi.org/10.1016/j.biocel.2005.06.012

Ogasawara, T., Ohnhaus, E. E., \& Hoensch, H. P. (1989). Glutathione and its related enzymes in the small intestinal-mucosa of rats-effects of starvation and diet. Research in Experimental Medicine, 189, 195-204. Retrieved from http://www.springerlink.com/content/n65103848841190r/fulltext

Petrovič, V., Novotný, J., Hisira, V., Link, R., Leng, L., \& Kováč, G. (2009). The impact of suckling and post-weaning period on blood chemistry of piglets. Acta Veterinaria Brno, 78, 365-371. http://dx.doi.org/10.2754/avb200978030365

Petry, C. J., Dorling, M. W., Pawlaw, D. B., Ozanne, S. E., \& Hales, C. N. (2001). Diabetes in old male offspring of rat dams fed a reduced protein diet. International Journal of Experimental Diabetes Research, 2, 139-143. http://dx.doi.org/ 10.1155/EDR.2001.139

Robertson, R. P., Harmon, J., Tran, P. O., Tanaka, Y. \& Takahashi, H. (2003). Glucose toxicity in beta-cells:type 2 diabetes, good radicals gone bad, and the glutathione connection. Diabetes, 52, 581-587. http://dx.doi.org/10.2337/diabetes.52.3.581

Roth, E., Oehler, R., Strasser, E., Exner, R., Wessner, B., Strasser, E. \& Spittler, A. (2002). Regulative potential of glutamine-relation to glutathione metabolism. Nutrition, 18, 217-221. http://dx.doi.org/10.1016/S0899-9007(01)00797-3

Sainz, R. D., \& Bentley, B. E. (1997). Visceral organ mass and cellularity in growth-restricted and refed beef steers. Journal of Animal Science, 75, 1229-1236. Retrieved from: http://jas.fass.org/content/75/5/1229

Scheaffer, A. N., Caton, J. S., Redmer, D. A., Arnold, D. R., \& Reynolds, L. P. (2004). Effect of dietary restriction, pregnancy, and fetal type on intestinal cellularity and vascularity in columbia and romanov ewes. Journal of Animal Science, 82, 3024-3033. Retrieved from http://jas.fass.org/content/82/10/3024

Sedlak, J., \& Lindsay, R. H. C. (1968). Estimation of total, protein bound and non-protein sulfhydryl groups in tissue with Ellmann's reagent. Analytical Biochemistry, 25, 192-205. Retrieved from http://bbs2.lsxk.cn/wForum/bbscon.php?bid=153\&id=9151\&ap=547

Shen, Z. M., Seyfert, H. M., Lohrke, B., Schneider, F., Zitnan, R., Chudy, A., ... Voigt, J. (2004). An energy-rich diet causes rumen papillae proliferation associated with more IGF type I receptors and increased plasma IGF-I concentrations in young goats. Journal of Nutrition, 134, 11-17. Retrieved from http://jn.nutrition.org/content/134/1/11.full.pdf+html

Siegel, G. J. (1999). Basic Neurochemistry: Molecular, Cellular and Medical Aspects. Philadelphia: Lippincott-Raven.

Sies, H. (1999). Glutathione and its role in cellular functions. Free Radical Biology and Medicine, 27, 916-921. http://dx.doi.org/10.1016/S0891-5849(99)00177-X

Sohal, R. S., \& Weindruch, R. (1996). Oxidative stress, caloric restriction, and aging. Science, 273, 59-63. 
http://dx.doi.org/10.1126/science.273.5271.59

Sreekumar, R., Unnikrishnan, J., Fu, A., Nygren, J., Short, K. R., Schimke, J., .. Nair, K. S. (2002). Effects of caloric restriction on mitochondrial function and gene transcripts in rat muscle. American Journal of Physiology-Endocrinology and Metabolism, 283, E38-E43. http://dx.doi.org/10. 1152/ajpendo.00387.2001

Swanson, K. C., Redmer, D. A., Reynolds, L. P., \& Caton, J. S. (1999). Ruminally undegraded intake protein in sheep fed low-quality forage: effect on weight, growth, cell proliferation, and morphology of visceral organs. Journal of Animal Science, 77, 198-205. Retrieved from http://jas.fass.org/content/77/1/198.long

Tohyama, Y., Takano, T., \& Yamamura, H. (2004). B cell responses to oxidative stress. Current Pharmaceutical Design, 10, 835-839. http://dx.doi.org/10.2174/1381612043452947

Tsai, P. H., Liu, J. J., Yeh, C. L., Chiu, W. C., \& Yeh S. L. (2012). Effects of glutamine supplementation on oxidative stress-related gene expression and antioxidant properties in rats with streptozotocin-induced type 2 diabetes. British Journal of Nutrition, 107, 1112-1118. http://dx.doi.org/10.1017/S0007114511004168

Ungerfeld, R., Hötzel, M. J., Scarsi, A., \& Quintans, G. (2011). Behavioral and physiological changes in early weaned multiparous and primiparous beef cows. Animal, 5, 1270-1275. http://dx.doi.org/10.1017/S1751731111000334

Wang, J. J., Ying T. Y., Wang, H. L., Shi, Z. X., Li, M. Z., ... Huang, L. Y. (2005). 2-d reference map of bacillus anthracis vaccine strain al6r proteins. Proteomics, 5, 4488-4495. http://dx.doi.org/10.1002/pmic.200401322

Yeh, K. Y. (1983). Small-intestine of artificially reared rat pups-effect of caloric-intake and dietary-composition on growth and disaccharidase activities. Journal of Nutrition, 113, 1496-1502. Retrieved from http://jn.nutrition.org/content/113/8/1496.long

Zhang, H. F., \& Zhang, Z. Y. (1998). Animal Nutrition Parameters and Feeding Standard (in Chinese). Beijing: China Agriculture Press. 